\title{
MAXIMUM CRIMINAL SANCTIONS FOR THE PERSONNEL OF Rape ACCORDING TO ARTICLE 285 KHUP (Case Study of Decision Number 131 / Pid.B / 2019 / PN.Cbi)
}

\author{
Usmanilala and Pitriadin \\ Departement of Law, IBLAM School of Law \\ Jalan Kramat Raya No.25, Jakarta Pusat
}

\begin{abstract}
Abstrack
The research objective was to analyze and describe the provision of non-maximum criminal sanctions for perpetrators of the crime of rape according to Article 285 KHUP in Decision Number 131 / Pid.B / 2019 / PN.Cbi and to analyze and describe judges' considerations in deciding cases of rape in decision No. 131 / Pid.B / 2019 / PN.Cbi. The research method used is the method of data analysis and library research / normative legal research, including primary legal materials, secondary legal materials, and tertiary legal materials. The results of the study show that the imposition of criminal sanctions is not maximum for the perpetrators of the crime of rape in Decision Number 131 / Pid.B / 2019 / PN.Cbi has not provided a sense of justice for victims because in practice law enforcement officials including the panel of judges who should be a mouthpiece of justice turned out to be did not give maximum sanctions to the perpetrators, the panel of judges in the case even openly ignored the condition of victims who had experienced trauma and depression. This provides clear evidence that there is still a lack of guaranteed protection for victims of sexual violence, especially rape in Indonesian criminal justice. Judges considerations in deciding criminal cases of rape in decision No. 131 / Pid.B / 2019 / PN.Cbi which imposes imprisonment for 3 (years), namely when the perpetrator is aware of the consequences, the perpetrator is in a healthy condition and is capable of considering his actions. The judge also did not see any justification or excuse reasons which could be the reason for the elimination of the criminal offense committed by the perpetrator. The Panel of Judges only saw incriminating matters, namely the perpetrator's actions which made witness Erica Alendha Sari experience psychological trauma. In this case the judge did not consider guaranteeing the fulfillment of the rights of victims of sexual violence, especially rape, for remedy that must be accommodated at every stage of the criminal justice system. For this reason, it is necessary to formulate laws and regulations that guarantee the fulfillment of the right to treatment including the right to confidentiality of identity, the right to protection related to guarantees of not being blamed and prosecuted for their testimony and also the right to recovery for victims of violence so that they can continue their life.
\end{abstract}

Keywords : Maximum Criminal Sanctions, Crime, Rape 


\title{
SANKSI PIDANA TIDAK MAKSIMUM BAGI PELAKU TINDAK PIDANA PEMERKOSAAN MENURUT PASAL 285 KHUP (Studi Kasus Putusan Nomor 131/Pid.B/2019/PN.Cbi)
}

\author{
Usmanilala, Pitriadin \\ Program Studi Sarjana Hukum, Sekolah Tinggi Ilmu Hukum IBLAM \\ Jalan Kramat Raya No. 25 Jakarta Pusat
}

\begin{abstract}
Abstrak
Tujuan penelitian untuk menganalisis dan mendeskripsikan pemberian sanksi pidana tidak maksimum bagi pelaku tindak pidana pemerkosaan menurut Pasal 285 KHUP pada Putusan Nomor 131/Pid.B/2019/PN.Cbi serta menganalisis dan mendeskripsikan pertimbangan hakim dalam memutus perkara tindak pidana pemerkosaan pada putusan No. 131/Pid.B/2019/PN.Cbi. Metode penelitian yang digunakan adalah metode analisis data dan penelitian kepustakaan (Library Research) / penelitian hukum normatif, meliputi bahan-bahan hukum primer, bahan hukum sekunder, dan bahan hukum tertier. Hasil penelitian menunjukkan bahwa Pemberian sanksi pidana tidak maksimum bagi pelaku tindak pidana pemerkosaan pada Putusan Nomor 131/Pid.B/2019/PN.Cbi belum memberikan rasa keadilan bagi korban karena dalam prakteknya aparat penegak hukum termasuk didalamnya majelis hakim yang seharusnya menjadi corong keadilan ternyata tidak memberikan sanksi yang maksimal kepada pelaku, majelis hakim dalam perkara tersebut bahkan secara terang-terangan mengabaikan kondisi korban yang mengalami trauma dan depresi. Hal tersebut memberikan bukti nyata bahwa masih minimnya jaminan perlindungan terhadap korban kekerasan seksual khususnya pemerkosaan dalam peradilan pidana Indonesia. Pertimbangan hakim dalam memutus perkara tindak pidana pemerkosaan pada putusan No. 131/Pid.B/2019/PN.Cbi yang memberikan sanksi pidana penjara selama 3 (tahun) yaitu pada saat melakukan perbuatannya pelaku sadar akan akibat yang ditimbulkan, pelaku dalam melakukan perbuatannya berada pada kondisi yang sehat dan cakap untuk mempertimbangkan perbuatannya. Hakim juga tidak melihat adanya alasan pembenar atau alasan pemaaf yang dapat menjadi alasan penghapusan pidana terhadap perbuatan yang dilakukan oleh pelaku. Majelis Hakim hanya melihat adanya hal-hal yang memberatkan yaitu perbuatan pelaku membuat saksi Erica Alendha Sari mengalami trauma psikis. Dalam perkara ini hakim tidak mempertimbangkan jaminan pemenuhan hak-hak korban kekerasan seksual khususnya pemerkosaan atas pemulihan yang harus diakomodir dalam setiap tahap sistem peradilan pidana. Untuk itu perlu adanya rumusan peraturan perundang-undangan yang memberikan jaminan pemenuhan hak atas penanganan termasuk didalamnya hak atas kerahasiaan identitas, hak atas perlindungan terkait dengan jaminan tidak disalahkan dan dituntut atas keterangannya dan juga hak atas pemulihan bagi korban kekerasan untuk dapat melanjutkan hidup.
\end{abstract}

Kata Kunci : Sanksi Pidana Maksimum, Tindak Pidana, Pemerkosaan 


\section{A. Pendahuluan}

Penjelasan tindak pidana pemerkosaaan adalah tindak pidana permerkosaan dapat menimpa semua orang tanpa terkecuali siapa saja dapat meenjadi korban pemerkosaaan, tidak memandang jenis kelamin mau pria atau pun wanita, tidak memandang usia, penampilan, fisik, kelompok sosial, cara berpakaian dan cara jalan seseorang.

Di media massa dapat kita ketahui banyak memberitakan mengenai tindak pidana pemerkosaan. Tindak pidana pemerkosaan yang terjadi sebenarnya jauh lebih banyak dari pada yang dilaporkan pada polisi dan yang diberitakan oleh media massa. Kebanyakan kasus baru terbongkar setelah korban mengalami gejala fisik serius, seperti pendarahan di dubur atau di vagina. Padahal masih ada begitu banyak kasus yang tidak menimbulkan trauma fisik yang berarti, namun berdampak serius pada psikologis korban.

Ancaman pelaku pemerkosaan membuat sebagian korban dan keluarga korban enggan melaporkan tindak pidana pemerkosaan yang telah menimpanya atau keluarganya dikarenakan takut, malu, depresi, trauma, dan rasa tidak berdaya, belum lagi perasaan bahwa masalah mereka justru akan bertambah rumit apabila dilaporkan kepada pihak yang berwajib. Korban harus menanggung stigma dari masyarakat ketika aib yang meimpa mereka diketahui oleh banyak orang. ${ }^{1}$

Tindak pidana pemerkosaan ditentukan dalam Pasal 285 KUHP Bab. XIV tentang kejahatan terhadap kesusilaan yaitu "Barang siapa dengan kekerasaan atau ancaman kekerasaaan memaksa

\footnotetext{
${ }^{1}$ http;//hukum.kompasiana.com/2012/02/05/kri minalitas-meningkat-hukum-indonesia- gagalmelindungi-rakyatnya/, diakses pada 03 Mei 2020
}

seorang wanita bersetubuh dengan dia di luar perkawinan, di ancam karena pemerkosaan dengan pidana penjara paling lama dua belas tahun”. Unsur-unsur yang terdapat dalam Pasal tersebut adalah:
1. Korban pemerkosaan adalah perempuan yang diluar perkawinan

2. Korban harus mengalami kekeraan atau ancaman kekerasan.

Berdasarkan unsur tersebut, maka dapat di ketahui bahwa tidak ada persetujuan dari pihak korban mengetahui niat dan tindak pelaku.

Ancaman pidana penjara dua belas (12) tahun pada kenyataan nya masih belum mampu mencegah terjadinya tindak pidana pemerkosaan dan membuat pelaku tindak pidana pemerkosaan menjadi jera, hal tersebut dikarenakan pada implementasinya pelaku tindak pidana pemerkosaan hanya diberikan sanksi pidana yang jauh dari pidana maksimum yang ditetapkan oleh undang-undang. Hal ini dapat di lihat dari contoh kasus pemerkosaan yang ada di dalam masyarakat.

Contoh kasusnya yaitu seorang laki laki bernama Taufik Bin Ayub Mulyadi (22), warga kampung Cibeurem Rt.003/001 Kelurahan /Kecamatan Cisarua Kabupaten Bogor, di bekuk oleh petugas setelah memperkosa seorang perempuan Erica Alendha Sari (18), pada saat melakukan pemerkosaan tersebut tersangka sempat menampar wajah dan mengancam dengan berkata "mau gak kalo mau saya bunuh" terhadap korban agar korban diam dan mau menuruti keinginan, perlakuan bejad pria ini terjadi pada tanggal 28 bulan Desember tahun 2018. Dalam perkara tersebut Jaksa Penuntut Umum menuntut perbuatan pelaku dengan pidana penjara selama 5 (lima) tahun sedangkan Hakim Pengadilan Negeri Cibinong menjatuhkan sanksi pidana 
kepada pelaku dengan pidana penjara selama 3 (tiga) tahun. ${ }^{2}$

Hal tersebut menjadi preseden buruk bagi korban kekerasan seksual lainnya namun juga membuat turunnya kepercayaan publik kepada aparat penegak hukum untuk menyelesaikan kasus-kasus kekerasan seksual, dan membuat korbankorban kekerasan seksual lainnya tidak mempercayai proses hukum. Selain itu Putusan ini jelas menjadi sebuah peringatan bagi para pembuat kebijakan dan pelaksana kebijakan untuk mengevaluasi apakah peraturan yang selama ini ada telah mampu memberikan perlindungan kepada korban dan apakah pelaksanaan praktik peradilan pidana khsusunya untuk kasus kekerasan seksual telah mengakomodir kepentingan korban. Karena berdasarkan kasus tersebut pelaku tindak pidana hanya diberiksan sanksi pidana selama 3 (tiga) tahun, hal tersebut jauh dari sanksi pidana maksimum yang telah ditetapkan oleh undang-undang, sehingga tidak mencerminkan rasa perlindungan hukum bagi korban.

Semua unsur tindak pidana harus terbukti untuk menjatuhkan hukuman pidana jika salah satu unsurnya tidak dapat terbukti maka dapat menyebabkan pelaku dibebaskan oleh pengadilaan. Maka dari itu unsur-unsur yang harus dibuktikan dalam Pasal 285 KUHP Bab. XIV tentang kejahatan terhadap kesusilaan adalah barang siapa dan dengan kekrasaan atau ancaman kekerasan memaksa seseorang wanita bersetubuh dengan dia di luar nikah.

Kedua unsur tersebut dengan unsur kekerasan atau ancaman kekerasan yang menyatai persetubuhan adalah unsur yang lebih sulit untuk dibuktikan dari pada unsur yang pertama. Sulitnya pembuktian unsur kekerasan atau ancaman kekerasan yang menyertai persetubuhan terjadi karena kurangnya atau lemah nya alat bukti untuk membuktikan terjadinya unsur

\footnotetext{
${ }^{2}$ Putusan Pengadilan Negeri Cibinong Nomor 131/Pid.B/2019/PN.Cbi
}

kekrasan atau ancaman kekerasaan yang menyertai persetubuhan biasanya hanya keterangan saksi saja yaitu saksi korban, tidak di dukung oleh alat bukti.

Berdasarkan uaraian latar belakang di atas, maka dalam penelitian ini dikemukakan perumusan masalah sebagai berikut:

1. Bagaiman pemberian sanksi pidana tidak maksimum bagi pelaku tindak pidana pemerkosaan menurut Pasal 285 KHUP pada Putusan Nomor 131/Pid.B/2019/PN.Cbi?

2. Bagaimana pertimbangan hakim dalam memutus perkara tindak pidana pemerkosaan pada putusan No. 131/Pid.B/2019/PN.Cbi?

\section{B. Metode Penelitian}

Penelitian merupakan sarana yang dipergunakan oleh manusia untuk memperkuat, membina sera mengembangkan ilmu pengetahuan. ${ }^{3}$ Sedangkan penelitian hukum merupakan suatu kegiatan ilmiah, yang didasarkan pada metode, sistematik dan pemikiran tertentu, yang bertujuan untuk mempelajari satu atau beberapa gejala hukum tertentu, dengan jalan menganalisanya. ${ }^{4}$

Serta memberikan gambaran terkait implementasi sanksi pidana maksimum bagi pelaku tindak pidana pemerkosaan guna pemberian perlindungan hukum bagi korban (Studi Kasus Putusan No. 131/Pid.B/2019/PN.Cbi). Metode penelitian yang digunakan adalah sebagai berikut :

\section{a. Tipe Penelitian}

Metode Penelitian yang digunakan dalam penulisan ini adalah metode hukum normatif, yaitu penelitian yang mencakup penelitian terhadap prinsip-prinsip hukum dan sistematikan hukum, sejarah hukum, dan perbandingan hukum mengenai implementasi sanksi pidana maksimum bagi pelaku tindak pidana pemerkosaan

3 Soerjono Soekanto, Pengantar Penelitian Hukum (Jakarta: Universitas Indonesia, 2014, hlm. 3.

${ }^{4}$ Ibid., hlm. 34. 
guna pemberian perlindungan hukum bagi korban (Studi Kasus Putusan No. 131/Pid.B/2019/PN.Cbi).

\section{b. Sifat Penelitian}

Sifat penelitian dalam skripsi ini adalah deskriptif analitis yaitu suatu penelitian yang dimaksudkan untuk memberikan data yang seteliti mungkin tentang manusia, keadaan atau gejalagejala lainnya. ${ }^{5}$ Penelitian ini dimaksudkan untuk menjelaskan serta memberikan gambaran terhadap Kekerasaan dalam hubungan.

\section{c. Data dan Sumber Data}

Lazimnya di dalam penelitian, dibedakan antara data yang diperoleh langsung dari masyarakat dan dari bahan pustaka. Yang pertama disebut dengan data primer atau data dasar dan yang kedua dinamakan dengan data sekunder. ${ }^{6}$ Dalam penelitian ini menggunakan data sekunder yang diperoleh melalui studi kepustakaan. Data kepustakaan digolongkan menjadi dua bahan hukum yaitu:

i. Bahan Hukum Primer,Bahan hukum yang dimaksud dalam penelitian ini adalah bahan-bahan hukum (peraturan perundang-undangan) yang megikat. Dalam penelitian ini bahan hukum primer yang digunakan adalah:

1. Undang-Undang Dasar 1945.

2. Kitab Undang -Undang Hukum Pidana.

3. Undang-Undang No. 48 Tahun 2009 Tentang Kekuasaan Kehakiman.

ii. Bahan Hukum Sekunder, Bahan hukum yang dimaksud merupakan bahan hukum yang memberikan, penjelasan mengenai bahan hukum primer. Bahan hukum sekunder yang digunakan adalah buku literature, buku hasil penelitian, tulisan dan makalah serta artikel terkait dengan topik sebagai referensi penulisan ini.

\section{d. Pengumpulan Data}

Pengumpulan data yang dilakukan dalam penelitian ini adalah melalui studi

\footnotetext{
${ }^{5}$ Soerjono Soekanto, Op. Cit., hlm.10

${ }^{6}$ Ibid., hlm. 12
}

kepustakaan yaitu membaca dan mempelajari berbagai macam buku ilmiah, buku wajib, dan peraturan perundang undangan serta melalui data data yang diakses melalui internet yang berkaitan dengan skripsi ini. Studi kepustakaan dilakukan dibeberapa tempat yaitu Perpustakaan Fakultas Hukum sekolah tinggi ilmu hukum Iblam dan perpustakaan Universitas Indonesia untuk mendapatkan data data yang diperlukan dalam pembuatan skripsi ini. ${ }^{7}$

\section{Hasil Penelitian dan Pembahasan}

SANKSI PIDANA TIDAK MAKSIMUM BAGI PELAKU TINDAK PIDANA PEMERKOSAAN MENURUT PASAL 285 KHUP PADA PUTUSAN NOMOR 131/PID.B/2019/PN.CBI

\section{Tindak Pidana Perkosaan Sebagai Delik Kesusilaan \\ Menurut Gerson W. Bawengan, ada} tiga pengertian kejahatan menurut penggunaannya, yaitu:

a. Pengertian secara praktis

Kejahatan adalah pelanggaran atas norma-norma keagamaan, kebiasaan, kesusilaan dan norma yang berasal dari adat istiadat yang mendapat reaksi, baik berupa hukuman maupun pengecualian.

b. Pengertian secara religious

Kejahatan identik dengan dosa dan setiap dosa terancam dengan hukuman api neraka.

c. Pengertian secara yuridis

Kejahatan yang telah dirumuskan dalam undang-undang, seperti dalam KUHP. ${ }^{8}$

Kartini Kartono menyatakan, bahwa secara sosiologis kejahatan adalah semua bentuk ucapan, perbuatan dan tingkah laku

${ }^{7}$ Ibid, hlm. 21

8 Abdul Wahid dan Muhammad Irfan, Perlindungan Terhadap Korban Kekerasan Seksual: Advokasi Atas Hak Asasi Perempuan, Bandung, Refika Aditama, 2001, hlm. 27 
yang secara ekonomis, politis dan sosiopsikologis sangat merugikan masyarakat, melanggar norma-norma susila, dan menyerang keselamatan warga masyarakat (baik yang telah tercakup dalam undangundang, maupun yang belum tercakup dalam undang-undang).

Beberapa pengertian kejahatan di atas menunjukkan bahwa ada tolak ukur terhadap suatu perbuatan dipandang sebagai kejahatan, yaitu berdasarkan norma-norma yang hidup dimasyarakat, baik itu norma agama, norma kesusilaan, norma kesopanan maupun norma hukum.

Dalam KUHP, tindak pidana perkosaan diatur pada Buku II Bab XIV tentang Kejahatan terhadap Kesusilaan. Secara singkat dan sederhana, delik kesusilaan adalah delik yang berhubungan dengan (masalah) kesusilaan. Dalam Kamus Besar Bahasa Indonesia, Kesusilaan ${ }^{10}$ diartikan sebagai perbuatan yang berkaitan dengan adab dan sopan santun; perilaku susila. Namun untuk menentukan seberapa jauh ruang lingkupnya tidaklah mudah, karena pengertian dan batas- batas kesusilaan itu cukup luas dan dapat berbeda-beda menurut pandangan dan nilai-nilai yang berlaku di dalam masyarakat. ${ }^{11}$

Dalam penentuan delik-delik kesusilaan, menurut Roeslan Saleh ${ }^{12}$ hendaknya tidak dibatasi pada pengertian kesusilaan dalam bidang seksual, tetapi juga meliputi hal-hal yang termasuk dalam penguasaan norma-norma kepatutan bertingkah laku dalam pergaulan masyarakat, misalnya meninggalkan orang

9 Kartini Kartono, Patologi Sosial, Jakarta, Raja Grafindo, 2001, hlm. 126

${ }^{10}$ Departemen Pendidikan Dan Kebudayaan, Kamus Besar Bahasa Indonesia edisi II,Jakarta, Balai Pustaka, 1997, hlm. 980;

11 Barda Nawawi Arief, Bunga Rampai Kebijakan Hukum Pidana, Bandung, PT.Citra Aditya Bakti, 1996, hlm. 291;

12 Dalam Tongat, Hukum Pidana Materiil Tinjauan Atas Tindak Pidana Terhadap Subyek Hukum Dalam KUHP, Jakarta, Djambatan, 2003, hlm. 109; yang perlu ditolong,penghinaan dan membuka rahasia. Sementara jika diamati berdasarkan kenyataan sehari-hari, persepsi masyarakat tentang arti kesusilaan lebih condong kepada kelakuan yang benar atau salah, khususnya dalam hubungan seksual ${ }^{13}$ (behaviour as to right or wrong, especially in relation to sexual matter).

Tindak pidana perkosaan termasuk salah satu kejahatan terhadap kesusilaan yang diatur dalam Pasal 285 KUHP, yang berbunyi: "Barangsiapa dengan kekerasan atau dengan ancaman kekerasan memaksa seorang wanita bersetubuh dengan dia di luar pernikahan, diancam karena melakukan perkosaan, dengan pidana penjara paling lama dua belas tahun".

Dalam ketentuan Pasal 285 diatas terdapat unsur-unsur untuk membuktikan ada atau tidaknya tindak pidana perkosaan, unsur-unsur yang dimaksud adalah sebagai berikut: ${ }^{14}$

a. Adanya kekerasan atau ancaman kekerasan

b. Memaksa seorang wanita

c. Bersetubuh di luar perkawinan dengan dia (pelaku)

Ad a) Adanya kekerasan atau ancaman kekerasan, artinya mempergunakan tenaga atau kekuatan jasmani tidak kecil secara tidak sah, misalnya memukul dengan tangan atau dengan segala senjata,menyepak, menendang, dan sebagainya sampai orang itu jadi pingsan atau tidak berdaya.

Ad b) Memaksa seorang wanita, artinya dengan kekerasan atau ancaman kekerasan memaksa perempuan yang bukan iastrinya bersetubuh dengan dia.

Ad c) Bersetubuh di luar perkawinan, artinya peraduan antara kemaluan laki-laki dan perempuan yang biasa dijalankan

13 Leden Marpaung, Kejahatan Terhadap Kesusilaan Dan Masalah Prevensinya, Jakarta, Sinar Grafika, 2004, hlm. 3;

14 R. Soesilo, KUHP Serta KomentarKomentarnya Lengkap Dengan Pasal Demi Pasal, Bandung, Karya Nusantara Cetakan X, 1988, hlm. 98, 209 
untuk mendapatkan anak, jadi anggota kelamin laki-laki harus masuk ke anggota kelamin perempuan, sehingga mengeluarkan mani dengan wanita yang bukan istrinya. ${ }^{15}$

Sementara tindak pidana perkosaan menurut RUU KUHP diatur dalam Bab XVI Tentang Tindak Pidana Kesusilaan Bagian Kelima Tentang Perkosaan dan Perbuatan Cabul Paragraf 1, yang berbunyi: Dipidana karena melakukan tindak pidana perkosaan, dengan pidana penjara paling singkat 3 (tiga) tahun dan paling lama 12 tahun:

1. Laki-laki yang melakukan persetubuhan dengan perempuan di luar perkawinan, bertentangan dengan kehendak perempuan tersebut;

2. Laki-laki yang melakukan persetubuhan dengan perempuan di luar perkawinan, tanpa persetujuan perempuan tersebut;

3. Laki-laki yang melakukan persetubuhan dengan perempuan, dengan persetujuan perempuan tersebut, tetapi persetujuan tersebut dicapai melalui ancaman untuk dibunuh atau dilukai;

4. Laki-laki yang melakukan persetubuhan dengan perempuan, dengan persetujuan perempuan tersebut karena perempuan tersebut percaya bahwa laki-laki tersebut adalah suaminya yang sah;

5. Laki-laki yang melakukan persetubuhan dengan perempuan yang berusia di bawah 14 (empat belas) tahun, dengan persetujuannya; atau

6. Laki-laki yang melakukan persetubuhan dengan perempuan, padahal diketahui bahwa perempuan tersebut dalam keadaan pingsan atau tidak berdaya".

\section{Tindak Pidana Perkosaan}

\section{Pengertian Tindak Pidana Perkosaan}

$\begin{array}{lccr}\begin{array}{c}\text { Menurut Kamus } \\ \text { Indonesia }\end{array} \text { yang } & \text { disusun } & \begin{array}{r}\text { Bahasa } \\ \text { oleh }\end{array} \\ \text { poerwardarminta, istilah perkosaan berasal } \\ \text { dari kata "perkosa" yang berarti : a. }\end{array}$

\footnotetext{
${ }^{15}$ Ibid, hlm. 210
}

Gagah;kuat b. Paksa; kekerasan; dengan paksa; dengan kekerasan; menjadi "memperkosa" yang artinya: a. Menundukkan dan sebagianya dengan kekerasan; menggagahi; memaksa dengan kekerasan b. Melanggar, menyerang dan sebagainya dengan kekerasan. Kemudian menjadi kata "perkosaan" yang artinya: a. Perbuatan memperkosa; penggahan; paksaan b. Pelanggaran dengan kekerasan. $^{16}$

Pemerkosaan merupakan istilah yang lazim digunakan pada bentuk tindakan paksaan dalam hubungan seks. Namun jika ditelusuri pemerkosaan memiliki makna yang tidak harus dipahami secara sempit, seperti istilah khusus dalam hubungan seks tetapi menggambarkan bentuk budaya perampasan hak yang berlangsung dalam kehidupan manusia. ${ }^{17}$

Bismar Siregar dalam bukunya Keadilan Hukum dalam Berbagai Aspek Hukum Nasional memberikan perumusan (batasan) pengertian perkosaan. Perkosaan dimaksudkan sebagai pemaksaan kehendak seseorang pada umumnya pria, tetapi bukan mustahil juga wanita kepada orang lain. Paksaan ini didirong oleh keinginan yang tidak terkendalikan walaupun ada saluran atau halal, tetapi dilakukan secara tidak halal. ${ }^{18}$

Menurut KUHP mengenai tindak pidana pemerkosaan tercantum dalam Pasal 285 yang menyebutkan bahwa pelaku pemerkosaan sebagai suatu tindak pidan adala " barang siapa dengan kekerasan atau ancaman kekerasan memaksa seorang wanita untuk melakukan persetubuhan dengan dirinya diluar perkawinan, maka ia karena telah melakukan perkosaan, dihukum dengan hukuman penjara selam lamanya 12 (dua

\footnotetext{
${ }^{16}$ Ibid, hlm. 742
}

Abdul Wahid dan Muhammad Irfan, Kekerasan Pada Korban Seksual, Bandung : Refika Aditama, 2000, hlm. 40

18 Bismar Siregar, Keadilan Hukum dalam Berbagai Aspek Hukum Nasional, Jakarta : Rajawali, 2005, hlm. 137 
belas) tahun". Jadi korban perkosaan adalah seorang wanita, yang dengan kekerasan atau dengan ancaman kekerasan dipaksa bersetubuh dengan lain di luar pernikahan.

Yang menjadi korban tindak pidana pemerkosaan kerap kali adalah wanita wanita termasuk anak, golongan lemah mental, fisik, sosial dalam arti luas.pengertian ini penting dalam rangka mengembangkan usaha - usaha atau upayaupaya untuk melindungi, melayani para korban pemerkosaan.

Antara pemerkosaan dengan pencabulam memiliki perbedaan dan haruslah diketahui perbedaannya tersebut. Perkosaan atau pemerkosaan berbeda dengan pencabulan sesuai penjelasan Pasal 285 KUHP, pada perkosaan dilakukan persetubuhan, apabila tidk dilaukan persetubuhan maka perbuatan- perbuatan tersebut hanya dapat dikenakan Pasal 289 KUHP yang menjelaskan perbuatan cabul. Dalam Pasal 289 KUHP terdapat persyaratan suatu perbuatan dikatakan sebagai perbuatan cabul dan pencabulan yaitu:

a. Adanya kekerasan atau ancaman kekerasan;

b. Adanya paksaan;

c. Adanya perbuatan yang merusak kesopanan atau melanggar kesusilaan. ${ }^{19}$

Dari unsur di atas pengertian cabul ialah segala perbuatan yang melanggar kesusilaan atau kesopanan atau perbuatan keji, contohnya adalah ciuman, merabaraba anggota tubuh dan/atau kemaluan alat kelamin.

\section{Unsur-unsur Tindak Pidana Perkosaan}

Unsur-unsur tindak pidana tersebut di atas dapat lagi disederhanakan sebagai unsur-unsur subjektif dan unsur-unsur objektif:

a. Unsur-unsur objektif dari suatu tinndak pidana adalah:

1. Melakukan (een doen), melakukan (een nalaten), perbuatan (een handeling)

2. Akibat teretentu (een bepaldgvolg)

\footnotetext{
${ }^{19}$ Ibid, hlm. 138
}

\section{Suatu keadaan (een omstandigheid)}

Yang kesemuanya itu dilarang dan diancam dengan hukuman oleh undangundang.

b. Unsur-unsur subjektif dari suatu tindak pidana adalah:

1. Pertanggungjawaban (toerekeningsvatbaarheid)

2. Kesalahan $(\text { schuld })^{20}$

Setiap tindakan yang bertentangan dengan hukum atau tidak sesuai dengan hukum, menyerang kepentingan masyarakat atau individu yang dilindungi hukum, menyerang kepentingan masyarakat atau individu yang dilindungi hukum, tidak disenangi oleh orang atau masyarakat, baik yang langsung atau tidak langsung karena tindakan tersebut. Pada umumnya untuk menyelasaikan setiap tindkan yang sudah dipandanng merugikan kepentingan umum di samping kepentingan perseorangan.

Adapun unsur-unsur tentang perkosaan menurut R. Sugandhi adalah :

1. Pemaksaan bersetubuh oleh laki-laki kepada wanita yang bukan menjadi istrinya;

2. Pemaksaan bersetubuh itu diikuti dengan tindakan atau anacaman kekerasan;

3. Kemaluan pria harus masuk pada lubang kemaluan wanita, dan;

4. Mengeluarkan air mani. ${ }^{21}$

Pendapat itu menunjukkan pada suatu perkosaan yang terjadi secara tuntas, artinya pihak pelaku (laki-laki pemerkosa) telah menyelsaikan perbuatannya hingga selesai (mengeluarkan air mani). Jika hal ini tidak sampai terjadi, maka secara eksplisit, apa yang dilakukan laki-laki tersebut belum patut dikategorikan sebgai perkosaan.

Tindak pidana perkosaan yang akan dibahas adalah tindak pidana perkosaan yang dilakukan seseorang yang melakukan poerbuatan perkosaan dengan seorang perempuan difabel dengan sengaja, melakukan kekerasan, tipu muslihat, dan

\footnotetext{
${ }^{20}$ Koesparmono Irsan, Op. Cit, hlm. 88-90

21 R. Sugandhi, KUHP dan Penjelasannya.
} Surabaya: Usaha Nasional, 2001, hlm. 71 
serangkaian kebohongan.

\section{Analisis Pemberian Sanksi Pidana Tidak Maksimum Bagi Pelaku Tindak Pidana Pemerkosaan Menurut Pasal 285 KHUP Pada Putusan Nomor 131/Pid.B/2019/PN.Cbi}

Pengaturan tindak pidana perkosaan dalam hukum pidana positif diatur dalam Pasal 285 KUHP. "Barang siapa dengan kekerasan atau ancaman kekerasan memaksa seorang perempuan bersetubuh dengan dia di luar perkawinan, diancam karena melakukan perkosaan dengan pidana penjara paling lama dua belas tahun." Pasal ini merupakan salah satu pengaturan tindak pidana kesusilaan yang bukan merupakan tindak pidana aduan melainkan tindak pidana biasa.

Pasal ini menekankan pada unsur pemaksaan dengan kekerasan dan ancaman kekerasan dari sudut pandang pelaku. Namun, pada penerapannya unsur ini sangat sulit dibuktikan berhubung sering terlambatnya proses aduan dari korban sehingga pembuktian tidak dapat maksimal, misalnya hasil visum et repertum yang tidak menunjukan adanya bekas kekerasan pada tubuh korban sebab jangka waktu yang lama dari saat kejadian. ${ }^{22}$

Hal tersebut sebagaimana hasil visum et repertum dalam perkara yang penulis kaji yang diperoleh hasil Visum Et Repertum Nomor : 194/FK/XI/2018/IKF tanggal 3 Januari 2019 yang diperiksa dr. Ajeng Normala, Sp.OG dokter Spesialis Obstetri dan Ginekologi dari Rumah Sakit Umum Daerah Ciawi Kabupaten Bogor telah melakukan pemeriksaan terhadap korban Erica Alendha Sari. Pada pemeriksaan korban perempuan berumur delapan belas tahun ini ditemukan selaput dara yang utuh (intak) serta kulit yang berwarna kemerahan pada leher sisi kanan dan kiri yang gambarannya sesui dengan perilaku seksual. Selanjutnya ditemukan memar-

22 Doortje D Turangan, Penerapan Pasal 285 KUHP Tentang Pelaku Tindak Pidana Perkosaan, Karya Tulis Ilmiah tidak diterbitkan, Manado, Universitas Sam Ratulangi, 2011, hlm. 21 memar pada batang hidung, kelopak bawah mata kanan, dada sisi kanan dan pada kiri, serta luka-luka lecet pada payudara kanan dan jari telunjuk tangan kiri yang diakibatkan oleh kekerasan tumpul yang tidak mengakibatkan penyakit atau halangan dalam menjalankan pekerjaan jabatan atau pencaharian. $^{23}$

Hal serupa juga terjadi dalam perkara Nomor 78/PID.B/2016/PN.Krg dimana pelaku datang ke rumah saksi Ngadinem dengan cara menggunakan anak tangga untuk naik ke atap rumah saksi Ngadinem lalu pelaku turun dari atap dan langsung berjalan menuju kamar saksi Ngadinem dan setelah sampai di kamar saksi Ngadinem, pelaku melihat saksi Ngadinem dalam keadaan tidur lalu pelaku mendatangi saksi Ngadinem dan menindih saksi Ngadinem dan pada waktu yang bersamaan pelaku melepas kaos (pakaian luar wanita), BH (pakaian dalam wanita/Bra/bustehouder), celana dalam yang dikenakan saksi Ngadinem, pelaku melepas celana luar dan celana dalam yang dikenakan pelaku, saksi Ngadinem melakukan perlawanan dengan cara meronta-ronta (hendak melepaskan diri) namun pelaku menekan bahu saksi Ngadinem sambil meremas-remas payudara saksi Ngadinem dan melumat bibir saksi Ngadinem kemudian pelaku merentangkan kaki saksi Ngadinem dan pada waktu yang bersamaan pelaku memasukkan alat kelamin (Penis) pelaku ke dalam alat kelamin (Vagina) saksi Ngadinem, saksi Ngadinem meronta-ronta sambil berteriak dan setelah alat kelamin pelaku masuk ke dalam alat kelamin (liang vagina) saksi Ngadinem pelaku menggerakkan pinggang pelaku sehingga alat kelamin pelaku keluar masuk (penetrasi) di dalam alat kelamin saksi Ngadinem selama kurang lebih 6 menit sampai pelaku mengeluarkan sperma di dalam alat kelamin saksi Ngadinem. ${ }^{24}$

Menurut Adami Chazawi dalam

\begin{tabular}{|c|c|}
\hline${ }^{23}$ Kasus & Putusan \\
\hline $\begin{array}{l}\text { 131/Pid.B/2019/PN.Cbi } \\
{ }^{24} \text { Kasus } \\
\text { 78/PID B/2016/PN.Krg }\end{array}$ & Putusan \\
\hline
\end{tabular}


Doortje D Turangan antara kekerasan dengan ketidakberdayaan perempuan itu terdapat hubungan kausal dan karena tidak berdaya itulah persetubuhan terjadi sebagai akibat dari perbuatan memaksa dengan menggunakan kekerasan dan ancaman kekerasan. Pengertian perbuatan memaksa (dwingen) adalah perbuatan yang ditujukan pada orang lain dengan menekan kehendak orang lain itu agar orang lain tadi menerima kehendak orang yang menekan atau sama dengan kehendaknya sendiri. ${ }^{25}$

Selain itu, perkosaan hanya dibatasi pada alat kelamin saja, sedangkan bisa saja perkosaan itu terjadi pada bagian tubuh yang lain, misalnya dubur, mulut, atau alat kelamin pria belum sampai masuk ke alat kelamin perempuan. Dengan demikian, korban akan semakin sulit untuk mendapatkan keadilan sedangkan korban yakni perempuan yang menanggung kerugian yang sangat besar.

Walaupun perkosaan merupakan tindak pidana biasa yang dapat dituntut tanpa harus ada laporan korban, tindak perkosaan sangat jarang tertangkap tangan. Selain itu kendala kondisi psikologis korban, sebagai salah satu efek buruk perkosaan, menjadi penghalang pelaporan sehingga menghambat proses pembuktian dan pemidanaan.

KUHP Indonesia yang berlaku saat ini menjelaskan bahwa pidana yang diancamkan pada tindak pidana perkosaan adalah maksimum 12 tahun penjara. Sedangkan, pada perkosaan terhadap anak dalam undang-undang perlindungan anak menetapkan maksimum umum pidana penjara adalah 15 tahun dan minimun khusus 3 tahun. Selain itu diancamkan denda paling banyak Rp 300.000.000,00 dan paling sedikit Rp 60.000.000,00.

Pasal 285 KUHP Indonesia tentang tindak pidana perkosaan ini tidak menerapkan pidana denda, sehingga korban tidak mendapatkan secara nyata kemenangan atas kasus pemerkosaan yang

\footnotetext{
${ }^{25}$ Ibid, hlm. 63
}

menimpanya kecuali rasa puas atas dipidananya pelaku tindak pidana pemerkosaan. Sehingga, untuk kejahatan perkosaan hakim harus berinisiatif sendiri untuk bersama dengan jaksa mengusahakan adanya ganti kerugian, yaitu kompensasi dan restitusi yang adil dan sesuai dengan kemamapuan yang bersangkutan. ${ }^{26}$

Selain itu dalam penerapan sanksi pidana bagi pelaku tindak pidana pemerkosaan tidak ditetapkan minimum pemidanaan. Sedangkan tidak ada jaminan bahwa kasus perkosaan yang dialami oleh korban dapat dibuktikan. Perkosaan sangat sulit dibuktikan biasanya karena bukti-bukti fisik perkosaan itu telah hilang disebabkan oleh lamanya jangka waktu kejadian dengan pelaporan. Pengaturan perkosaan dalam hukum pidana positif tidak mengakomodir kepentingan perlindungan korban tetapi hanya berorientasi pada perbuatan pelaku sehingga banyak kendala yang dihadapi dalam mengadili kasus perkosaan.

Jika penilis kaitkan dengan feminist criminology legal jurisprudence yang mengkritik KUHP. KUHP di Indonesia tidak menganggap perempuan sebagai manusia yang bermartabat, yaitu manusia yang punya individualitas seperti pria. Sebaliknya perempuan dianggap sebagai makhluk tubuh seksualitas belaka. Hal ini nampak misalnya pada sejumlah pasal dalam KUHPidana. Salah satunya adalah tentang perkosaan (Pasal 285) yang mengisyaratkan korban harus bukan isteri sendiri dan harus terjadi dalam bentuk "hubungan seksual" yang keputusan Hooge Raad (Mahkamah Agung Hindia Belanda) tanggal 5 Februari diartikan sebagai "penetrasi penis ke vagina". ${ }^{27}$

Dengan mengutip feminis Catherine MacKinnon, Nursyahbani Katjasungkana

${ }^{26}$ Arif Gosita, Relevansi Viktimologi : Dengan Pelayanan Terhadap Para Korban Perkosaan, Jakarta; Ind.Hill-Co., 1987, hlm. 21.

${ }^{27}$ https://www.scribd.com/document/32869682 2/FEMINIST-JURISPRUDENCE, diakses pada tanggal 18 Juli 2020, hlm. 1 
menganggap perumusan tersebut sebenarnya didasarkan pada cara pandang pria "heteroseksual" tentang hubungan seks, karena mensyaratkan terjadinya "penetrasi penis ke vagina". Dengan kata lain, kekerasan seksual terhadap perempuan yang tidak dalam bentuk "penetrasi penis ke vagina" tidak akan dianggap sebagai kejahatan terhadap HAM perempuan, mungkin hanya dianggap sebagai kejahatan biasa. Para feminis yakin bahwa sejarah ditulis melalui sudut pandang laki-laki dan sama sekali tidak merefleksikan peranan perempuan dalam pembuatan dan penyusunan sejarah. Sejarah buatan laki-laki tersebut telah menciptakan konsep-konsep tentang keberadaan manusia, potensi gender dan rekayasa sosial yang menghasilkan bahasa, logika dan struktur hukum yang mencerminkan karakter dan nilai-nilai dari sudut pandang laki-laki. Maka begitulah, bagaimana perkosaan dirumuskan dari perspektif pelaku (pria). Pasal perkosaan ini tidak dirumuskan dari perspektif korban (perempuan). Hal ini terjadi karena ilmu hukum (yang ditulis dalam perspektif teori Positivisme Hukum) memang tidak mampu dan tidak mau menafsirkan diskriminasi gender suatu tafsir yang mau mengungkap relasi kuasa yang tidak setara antara perempuan dan pria yang terjadi di masyarakat. $^{28}$

Padahal tindak pidana perkosaan dapat melukai akal dengan adanya kemungkinan gangguan psikologis, bahkan membahayakan harta dengan merampas kemampuan ekonomi dan mengancam jiwa dengan kemungkinan kematian atau luka berat serta kemungkinan tindak pidana lainnya seperti abortus. Untuk itu penjatuhan sanksi pidana terhadap Pelaku tindak pidana perkosaan seperti dalam kasus yang penulis kaji dengan pidana penjara selama 3 (tiga) tahun dirasakan kurang sepadan dengan dampak yang ditimbulkan bagi korban tindak pidana perkosan tersebut.

\footnotetext{
${ }^{28}$ Ibid, hlm. 25
}

Selain itu KUHAP tidak mengatur bahwa putusan pemidanaan harus sesuai atau di bawah dari tuntutan Jaksa/Penuntut Umum. Dalam kasus tertentu dimana ditemukan fakta persidangan terdapat halhal yang memberatkan sehingga hakim memiliki keyakinan untuk menjatuhkan pidana lebih tinggi dari tuntutan jaksa, maka hukuman itu tidaklah melanggar hukum acara pidana. Untuk memperjelas masalah ini kami kutipkan bagian lain dari kesimpulan penelitiantersebut.

Merupakan kewenangan daripada hakim memutus sesuai fakta persidangan dan keyakinannya memberikan pemidanaan melebihi tuntutan Jaksa Penuntut Umum jika dirasa adil dan rasional. Apalagi merupakan sebuah realitas bahwa tuntutan dari Jaksa Penuntut Umum tidaklah selalu sama atau sesuai dengan batasan maksimal ancaman pidana yang terdapat secara eksplisit dalam peraturan perundangundangan. Hakim dapat memutus lebih tinggi dari tuntutan Jaksa Penuntut Umum, namun tidak boleh melebihi batas maksimum ancaman pidana yang ditentukan Undang-Undang. ${ }^{29}$

Meskipun ada kebebasan dan independensi hakim dalam menjatuhkan putusan, bukan berarti tak ada batasan. Batasan-batasan dimaksud antara lain:

1. Tidak boleh melebihi ancaman maksimal Pasal yang didakwakan.

2. Tidak diperkenankan memberikan putusan pemidanaan yang jenis pidananya (strafsoort) tidak ada acuannya dalam KUHP atau peraturan pidana di luar KUHP. ${ }^{30}$

3. Putusan pemidanaan itu harus memberikan pertimbangan yang cukup berdasarkan bukti. ${ }^{31}$

29 Sudharmawatiningsih, Pengkajian tentang Putusan Pemidanaan Lebih Tinggi dari Tuntutan Jaksa Penuntut Umum: Laporan Penelitian, Jakarta: Puslitbang Hukum dan Peradilan Badan Litbang Diklat Kumdil Mahkamah Agung, 2015, hlm. 63.

${ }^{30}$ Ibid.

31 Lilik Mulyadi, Seraut Wajah Putusan Hakim dalam Hukum Acara Pidana Indonesia: Perspektif, Teoritis, Praktik, Teknik Membuat dan 
Untuk itu dalam penerapan sanksi pidana bagi pelaku tindak pidana perkosaan seharusnya memberikan sanksi maksimal, seperti memberikan hukuman mati mengingat besarnya akibat, kerusakan dan kerugian yang diderita oleh korban secara khusus dan keamanan masyarakat secara umum. Begitu pula harapannya pengaturan tindak pidana perkosaan pada masa yang akan datang, pengaturan sanksinya memberikan perhatian terhadap akibat-akibat kejahatan.

Seperti dikemukakan di atas mengenai akibat kerusakan yang ditimbulkan tindak pidana perkosaan, terdapat kemungkinan adanya akibat matinya korban atau timbul luka berat. Luka berat dijelaskan dalam Pasal 90 KUHP, yaitu :

1) Jatuh sakit atau mendapat luka yang tidak memberi harapan akan sembuh sama sekali, atau yang menimbulkan bahaya maut;

2) Tidak mampu terus-menerus untuk menjalankan tugas jabatan atau pekerjaan pencarian;

3) Kehilangan salah satu pancaindera;

4) Mendapat cacat berat;

5) Menderita sakit lumpuh;

6) Terganggunya daya pikir selama empat minggu lebih;

7) Gugur atau matinya kandungan seorang perempuan.

Oleh karena itu, perlu ditambahkan adanya rumusan pemberatan pidana yang mengakomodir munculnya akibat lain diluar bentuk rumusan pokok. Seperti halnya dalam pengaturan tindak pidana penganiayaan, Pasal 351 KUHP menunjukan bahwa pengaturan pemberatan pidana dapat dilakukan. Bentuk pokok pada ayat (1) menyebutkan bahwa penganiayaan diancam dengan pidana penjara paling lama dua tahun delapan bulan atau pidana denda paling banyak empat ribu lima ratus rupiah. Kemudian, pada ayat (2) dan (3) terdapat pemberatan pidana apabila terjadi luka

Permasalahannya. Bandung: Citra Aditya Bakti, 2010, h. 195 berat diancam dengan lima tahun penjara dan apabila mengakibatkan kematian diancam dengan pidana penjara tujuh tahun. Oleh karena itu, pengaturan pemberatan pidana seperti pada pengaturan tindak pidana peganiayaan dapat dilakukan pada pengaturan tindak pidana perkosaan.

Sistem penetapan jumlah atau lamanya ancaman pidana di Indonesia menggunakan sistem atau pendekatan absolut atau indefinite dimana setiap tindak pidana ditetapkan bobot atau kualitasnya dengan menetapkan ancaman pidana maksimum atau dapat juga ancaman minimumnya. ${ }^{32}$ Adapun pola maksimum dan minimum pidana yang ditentukan untuk pidana penjara pada khususnya disebutkan dalam Pasal 12 KUHP.

1) Pidana penjara ialah seumur hidup atau selama waktu tertentu.

2) Pidana penjara selama waktu tertentu paling pendek satu hari dan paling lama limabelas tahun berturut-turut.

3) Pidana penjara selama waktu tertentu boleh dijatuhkan untuk dua puluh tahun berturut-turut dalam hal kejahatan yang pidananya hakim boleh memilih antara pidanamati, pidana seumur hidup, dan pidana penjara selama waktu tertentu, atau antarapidana penjara seumur hidup dan pidana penjara selama waktu tertentu; begitu jugadalam hal batas lima belas tahun dilampaui sebab tambahanan pidana karenaperbarengan, pengulangan atau karena ditentukan Pasal 52.

4) Pidana penjara selama waktu tertentu sekali-kali tidak boleh melebihi dua puluh tahun.

Ancaman pidana penjara maksimal 12 tahun, batas bawah untuk ancama pidana golongan sangat berat, digabungkan dengan ancaman pidana minimum 3 tahun, yang merupakan batas atas dari golongan "berat". Pada prinsipnya pidana minimum

32 Barda Nawawi Arief, Bunga Rampai Kebijakan Hukum Pidana Perkembangan Penyususnan Konsep KUHP Baru, Kencana Prenada Media Group, Jakarta, 2010, hlm. 116 
khusus seperti ini merupakan perkecualian untuk tindak pidana tertentu yang dipandang sangat merugikan, membahayakan atau meresahkan masyarakat dan tindak pidana yang dikualifikasikan atau diperberat oleh akibatnya. $^{33}$

Perkosaan sudah dipandang sebagai tindak pidana yang membahayakan bagi masyarakat, pada masa yang akan datang. Namun sayangnya, ancaman pidana pada KUHP maupun rancangan KUHP belum cukup mengakomodir kemungkinan akibat luka berat dan kematian walaupun timbul bukan sebagai maksud dari perbuatan. Sanksi yang diancamkan merupakan sanksi pertengahan yang sepertinya sukar untuk digolongkan ke dalam tindak pidana yang sangat serius. Demikian halnya dengan tindak pidana perkosaan, harus memperhatikan akibat yang ditimbulkan terhadap korban.

Secara substansi, tindak pidana perkosaan juga merupakan kejahatan yang membahayakan keamanan umum walaupun tidak termasuk pembahasannya dalam Bab VII KUHP tersebut. Perkosaan bukan merupakan tindak pidana yang hanya berdampak pada pribadi- pribadi yang bersangkutan, tetapi juga menyangkut rasa aman atas keberlangsungan hidup dan masa depan masyarakat. Hal ini mengingat masyarakat Indonesia yang bersifat komunal, selain itu tindak pidana perkosaan merupakan perbuatan yang bertentangan dengan nilai-nilai fundamental yang berlaku dalam masyarakat dan oleh masyarakat dianggap patut untuk dijatuhi hukuman yang berat.

Jadi rumusan pengaturan sanksi perkosaan dapat dibuat bertingkat pula dengan menambahkan pemberatan pidana pada perbuatan yang berakibat pada luka berat yaitu pidana penjara maksimum lima belas tahun, mengingat luka berat yang ditimbulkan membahayakan nyawa korban. Dan, maksimum pidana penjara seumur hidup atau pidana penjara waktu tertentu

\footnotetext{
${ }^{33}$ Ibid, hlm. 125
}

selama dua puluh tahun bagi perkosaan yang berakibat kematian. Pidana penjara tersebut harapannya memberikan sebuah kontribusi pencapaian seluruh aspek tujuan pemidanaan, baik aspek perlindungan masyarakat dan aspek perbaikan pelaku

\section{PERTIMBANGAN HAKIM DALAM MEMUTUS PERKARA TINDAK PIDANA PEMERKOSAAN PADA PUTUSAN NO. 131/PID.B/2019/PN.CBI}

\section{Tindak Pidana Pemerkosaan Pada Putusan Nomor 131/Pid.B/2019/ PN.Cbi Kasus Posisi}

Pada bagian ini diuraikan mengenai tindak pidana pemerkosaan, dengan identitas pelaku sebagai berikut :

$\begin{array}{ll}\text { Nama lengkap } & : \text { Taufik Bin Ayub } \\ & \text { Mulyadi } \\ \text { Tempat lahir } & : \text { Bogor } \\ \text { Umur/Tanggal lahir } & : \text { 22 Tahun / 7 } \\ & \text { November 1996 } \\ \text { Jenis kelamin } & : \text { Laki-laki } \\ \text { Kebangsaan } & \text { : Indonesia } \\ \text { Tempat tinggal } & \text { : Kp.Cibeurem } \\ & \text { Rt.003/001 Kelurahan/ } \\ & \text { Kecamata Cisarua } \\ & \text { Kabupaten Bogor }\end{array}$

Agama : Islam

Pekerjaan : Buruh

Pelaku Taufik Bin Ayub Mulyadi pada hari Jumat tanggal 28 Desember 2018 sekira pukul 20.00 Wib atau setidaktidaknya pada suatu waktu yang masih dalam Tahun 2018, bertempat di kebun yang beralamat curug erwin di Kp Burujul Kel. Cisarua Kab. Bogor, atau setidaktidaknya pada suatu tempat tertentu yang masih termasuk dalam daerah hukum Pengadilan Negeri Cibinong berwenang mengadilinya dan memeriksanya, dengan kekerasan atau ancaman kekerasan memaksa seorang wanita bersetubuh dengan dia diluar perkawinan.

Berawal pada hari jumat tanggal 28 Desember 2018 sekira jam 15.54 wib pelaku Taufik Bin Ayub Mulyadi mengirimkan Pesan Suara Ke No Hp saksi 
korban Erica Alendha Sari yang isi Pesan suara tersebut bahwa pelaku berminat untuk membeli topi dan dompet yang pernah ditawarkan oleh saksi korban Erica Alendha Sari dan untuk membeli barang-barang tersebut pelaku bermaksud akan pinjam uang ke bos pelaku supaya bos pelaku percaya maka barang berupa Topi dan Dompet harus ada berikut dengan saksi korban Erica Alendha Sari.

Kemudian sekitar jam 18.00 wib, saksi korban Erica membalas pesan suara yang dikirim pelaku melalui Hp saksi Korban Erica Merk Advan. Selanjutnya pelaku dengan saksi korban Erica sepakat untuk bertemu dengan pelaku, lalu sekitar Jam 19.21 Wib saksi korban Erica dan adik saksi Erica yang bernama Galang dijemput oleh Pelaku Taufik Bin Ayub Mulyadi didepan villa dengan menggunakan sepeda motor Yamaha Vega F-2633-KN warna hitam menuju ke daerah Jogjogan Cisarua Bogor. Sesampainya didaerah Jogjogan adik kandung saksi korban Erica yang bernama GALANG diturunkan oleh pelaku dengan alasannya bahwa bos pelaku tidak mau ada orang lain waktu pembelian barang dari saksi korban Erica. Pada saat diwarung pelaku bilang kepada tukang warung mengatakan "sebentar mau ke atas dulu" dan pada waktu di warung Pelaku Taufik Bin Ayub Mulyadi berpura-pura ingin melihat barang yang akan saksi korban Erica jual berupa topi dan dompet, kemudian barang itu diphoto oleh pelaku Taufik Bin Ayub Mulyadi lalu Photo tersebut oleh pelaku seolah-olah sudah dikirimkan ke Bosnya yang akan beli barang tersebut.

Selanjutnya saksi korban Erica kembali diminta oleh Pelaku Taufik Bin Ayub Mulyadi untuk naik menuju kerumah bosnya dan tanpa curiga saksi korban Erica ikut naik ke motor yang dibawa oleh Pelaku Taufik Bin Ayub Mulyadi Menuju ke daerah Burujul Cisarua Bogor melewati Villa Rudian dan tidak lama kemudian masuk ke Gg dan menuju ke Villa Kosong. Sesampainya di Villa kosong tersebut sepeda motor yang dikendarai pelaku berhenti dan di parkir. Selanjutnya saksi korban Erica diajak untuk menemui bosnya pelaku dan saksi korban Erica mengikuti kemauan pelaku untuk menemui bos pelaku. Selanjutnya saksi korban Erica dibawa ke Kebun Kosong dan setelah itu pelaku bilang kepada saksi korban Erica untuk nunggu di lokasi tersebut dengan alasan bos pelaku akan datang dan pada saat saksi korban Erica menunggu tiba-tiba pelaku mengajak berhubungan badan dan saksi korban Erica sempat marah, namun Pelaku tambah garang dengan merampas HP saksi korban Erica dan dibuang ke semak-semak.

Lalu saksi korban Erica sempat menampar Pelaku dengan kantong Plastik yang dibawa saksi korban Erica yang didalamnya ada barang yang akan saksi korban jual, setelah ada perlawanan dari saksi korban Erica lalu Pelaku langsung memeluk saksi korban Erica dan menjatuhkan ke rumput kemudian saksi korban Erica dicekik oleh pelaku sambil bicara kepada saksi korban "Mau Gak Kalo Gak Mau Saya Bunuh" dan kata-kata itu pelaku sempat beberapa kali mengucapkan kepada saksi korban Erica namun saksi korban Erica tetap diam karena ketakutan.

Kemudian Pelaku Taufik Bin Ayub Mulyadi tetap mencekik leher saksi korban Erica dan pelaku langsung menciumi leher saksi korban Erica dan dilanjutkan dengan membekap mulut dan hidung dan Pelaku waktu itu mengeluarkan ancaman lagi dengan kata-kata yang sama, karena ada perlakuan kasar dan ada ancaman maka saksi korban Erica bilang kepada Pelaku "Iya". Setelah itu pelaku melepaskan bekapan mulut saksi korban Erica dan pelaku langsung membuka pakaiannya hingga telanjang bulat dan saksi korban Erica pada saat itu masih berpakaian waktu pelaku hendak membuka baju saksi korban Erica sempat akan melarikan diri namun ditahan oleh Pelaku Taufik Bin Ayub Mulyadi. Kemudian pelaku membuka paksa celana yang saksi korban Erica kenakan 
hingga semuanya terlepas dan setelah itu saksi korban Erica diseret lagi masuk ke kebun yang gelap dan setelah ditempat yang gelap saksi korban didorong dan jatuh terlentang.

Selanjutnya Pelaku Taufik Bin Ayub Mulyadi memutar Film Porno melalui Handphone Evercross (DPB) milik pelaku dan saksi korban disuruh melihat Film porno tersebut, sedangkan Pelaku Taufik Bin Ayub Mulyadi melakukan cabul dengan cara menjilati kemaluan dan paha saksi korban Erica. Selanjutnya Pelaku Taufik Bin Ayub Mulyadi Memeluk saksi korban Erica dengan kasar dan saksi korban Erica merasakan kemaluan Pelaku beberapa kali dicoba untuk dimasukkan ke dalam alat kelamin saksi korban Erica namun tidak berhasil karena saksi korban Erica berontak.

Kemudian saksi korban Erica di paksa untuk pegang alat kelamin pelaku supaya tegang dan setelah alat kelamin pelaku tegang mencoba kembali memasukan alat kelaminnya kedalam kemaluan saksi korban Erica, dan saksi korban Erica merasakan masuk hampir setengah. Selanjutnya saksi korban Erica disuruh untuk merangsang kemaluan pelaku lagi untuk dikeluarkan lalu saksi korban Erica mengikuti kemauan pelaku karena takut dan melakukan apa yang diperintah Pelaku hingga saksi korban merangsang alat kelamin pelaku dengan tangan dan saksi korban Erica melihat sperma keluar dari alat kelamin pelaku.

Setelah itu Pelaku Taufik Bin Ayub Mulyadi memakai kembali pakaian begitu juga saksi korban Erica. Dan setelah berpakaian langsung menuju ke parkiran motor yang setelah itu berangkat dan menuju ke adik saksi korban Erica yang nunggu diwarung. Setelah itu saksi korban Erica diantar ke Villa namun berhenti di warung dekat Villa dimana saksi korban Erica tinggal dan pelaku bilang kepada saksi korban Erica besok di jemput lagi dan saksi korban Erica tidak komentar atas ajakan Pelaku Taufik Bin Ayub Mulyadi dan saksi korban Erica masuk ke rumah. Selanjutnya saksi korban Erica bilang kepada Orang tua saksi korban Erica. Pada malam harinya Pelaku Taufik Bin Ayub Mulyadi mengirimkan pesan suara dengan kata-kata permintaan maaf.

Berdasarkan Visum Et Repertum Nomor : 194/FK/XI/2018/IKF tanggal 3 Januari 2019 yang diperiksa dr. Ajeng Normala, Sp.OG dokter Spesialis Obstetri dan Ginekologi dari Rumah Sakit Umum Daerah Ciawi Kabupaten Bogor telah melakukan pemeriksaan terhadap korban Erica Alendha Sari.

Pada pemeriksaan korban perempuan berumur delapan belas tahun ini ditemukan selaput dara yang utuh (intak) serta kulit yang berwarna kemerahan pada leher sisi kanan dan kiri yang gambarannya sesui dengan perilaku seksual. Selanjutnya ditemukan memar-memar pada batang hidung, kelopak bawah mata kanan, dada sisi kanan dan pada kiri, serta luka-luka lecet pada payudara kanan dan jari telunjuk tangan kiri yang diakibatkan oleh kekerasan tumpul yang tidak mengakibatkan penyakit atau halangan dalam menjalankan pekerjaan jabatan atau pencaharian.

\section{Dakwaan dan Tuntutan Jaksa Penuntut Umum}

Berdasarkan kronologis yang diuraikan di atas, Jaksa Penuntut Umum mendakwa dan menuntut perbuatan pelaku sebagai berikut:

a. Dakwaan

Perbuatan pelaku tersebut diatas sebagaimana yang diatur dan diancam pidana dalam Pasal 285 KUHP

b. Tuntutan

1) Menyatakan pelaku Taufik Bin Ayub Mulyadi telah terbukti secara sah dan meyakinkan bersalah melakukan tindak pidana "dengan ancaman kekerasan memaksa seorang wanita bersetubuh dengan dia di luar perkawinan" 
sebagaimana diatur dan diancam pidana Pasal 285KUHP.

2) Menjatuhkan pidana kepada pelaku Taufik Bin Ayub Mulyadi dengan pidana penjara selama 5 (lima) tahun dikurangi selama pelaku berada dalam tahanan, dengan perintah agar pelaku tetap berada dalam tahanan

3) Menyatakan barang bukti berupa 1 (satu) buah Hp Advan, 1 (satu) buah sandal, 1 (satu) buah celana levis warna hitam yang kancing rusak, 1 (satu) buah kaos warna Pink, 1 (satu) buah sweter corak coklat pink yang ada bekas tanah, 1 (satu) buah kerudung warna hitam, 1 (satu) buah celana dalam yang ada Noda darah, 1 (satu) buah kaos sinlet warna pink yang ada kotoran tanah, 1 (satu) buah BH warna biru, 1 (satu) buah masker warna oren, 1 (satu) buah topi warna hitam, 1 (satu) buah dompet kulit dikembalikan saksi Erica Alendha, serta 1 (satu) unit sepeda motor Yamaha Vega F-2633 KN, STNK sepeda motor Yamaha Vega F-2633-KN an. Suhend, 1 (satu) buah kunci kontak Yamaha Vega F-2633 KN dikembalikan kepada pemiliknya saksi Yudi.

4) Menetapkan supaya pelaku dibebani membayar biaya perkara sebesar Rp.2.000,- (dua ribu rupiah).

\section{Putusan Hakim}

Sedangkan hakim Pengadilan Negeri Cibinong memutuskan sebagai berikut:

a. Menyatakan Pelaku Taufik Bin Ayub Mulyadi terbukti secara sah dan meyakinkan bersalah melakukan tindak pidana "Perkosaan".

b. Menjatuhkan pidana kepada Pelaku Taufik Bin Ayub Mulyadi tersebut oleh karena itu dengan pidana penjara selama 3 (tiga) tahun.

c. Menetapkan masa penangkapan dan penahanan yang telah dijalani oleh Pelaku dikurangkan seluruhnya dari pidana yang dijatuhkan. d. Menyatakan barang bukti berupa 1 (satu) buah Hp Advan, 1 (satu) buah sandal, 1 (satu) buah celana levis warna hitam yang kancing rusak, 1 (satu) buah kaos warna Pink, 1 (satu) buah sweter corak coklat pink yang ada bekas tanah, 1 (satu) buah kerudung warna hitam, 1 (satu) buah celana dalam yang ada Noda darah, 1 (satu) buah kaos sinlet warna pink yang ada kotoran tanah, 1 (satu) buah BH warna biru, 1 (satu) buah masker warna oren, 1 (satu) buah topi warna hitam, 1 (satu) buah dompet kulit dikembalikan saksi Erica Alendha, serta 1 (satu) unit sepeda motor Yamaha Vega F-2633 KN, STNK sepeda motor Yamaha Vega F-2633$\mathrm{KN}$ an. Suhend, 1 (satu) buah kunci kontak Yamaha Vega F-2633 KN dikembalikan kepada pemiliknya saksi Yudi.

e.

Membebankan $r$ kepada
Pelaku untuk membayar biaya
perkara sejumlah Rp. 2.000,- (dua
ribu rupiah).

Analisis Pertimbangan Hakim dalam memutus perkara tindak pidana pemerkosaan pada putusan No. 131/Pid.B/2019/PN.Cbi.

Suatu proses peradilan berakhir dengan putusan akhir (vonnis) yang didalamnya terdapat penjatuhan sanksi pidana (penghukuman), dan di dalam putusan itu hakim menyatakan pendapatnya tentang apa yang telah dipertimbangkan dan apa yang menjadi amar putusannya. Sebelum sampai pada tahapan tersebut, ada tahapan yang harus dilakukan sebelumnya, yaitu tahapan pembuktian dalam menjatuhkan pidana terhadap pelaku.

Dalam menjatuhkan Pidana, hakim harus berdasarkan pada keterangan saksi, keterangan pelaku dan barang bukti yang kemudian dari hal tersebut hakim memperoleh keyakinan bahwa tindak pidana yang didakwakan benar-benar terjadi dan pelakulah yang melakukannya.

Selain dari apa yang dijelaskan Penulis 
di atas, yang perlu dilakukan oleh hakim adalah untuk dapat dipidananya si pelaku, disyaratkan bahwa tindak pidana yang dilakukannya itu memenuhi unsur-unsur yang telah ditentukan dalam Undangundang. Dilihat dari sudut terjadinya tindakan yang dilarang, seseorang akan dipertanggungjawabkan atas tindakantindakan tersebut, apabila tindakan tersebut melawan hukum serta tidak ada alasan pembenar atau peniadaan sifat melawan hukum untuk pidana yang dilakukannya. Dilihat dari sudut kemampuan bertanggung jawab maka hanya seseorang yang mampu bertanggung jawab yang dapat dipertanggung jawabkan atas perbuatannya, serta tidak ada alasan pembenar atau peniadaan sifat melawan hukum untuk pidana yang dilakukannya. Selain itu dilihat dari sudut kemampuan bertanggung jawab maka hanya seseorang yang mampu bertanggung jawab yang dapat dipertanggung jawabkan atas perbuatannya.

Dalam perkara ini Jaksa Penutu Umum menuntut perbuatan pelaku Taufik Bin Ayub Mulyadi terbukti secara sah menurut hukum dan meyakinkan bersalah melakukan tindak pidana :"Pemerkosaan", sebagaimana diatur dan diancam pidana dalam Pasal 285 KUHP, dengan tuntutan sanksi pidana penjara selama 5 (lima) tahun dikurangi selama pelaku ditahan sementara dengan perintah pelaku tetap ditahan. Berdasarkan dakwaan dan tuntutan jaksa penuntut umum, hakim menyatakan pelaku Taufik Bin Ayub Mulyadi telah terbukti secara sah dan meyakinkan bersalah melakukan tindak pidana "Pemerkosaan", sehingga hakim menjatuhkan pidana terhadap Pelaku Taufik Bin Ayub Mulyadi, dengan pidana penjara selama 3 (tiga) tahun, hal tersebut tidak sesuai dengan tuntutan dan dakwaan Jaksa Penuntut Umum.

Jika kaji lebih dalam terkait ketentuan Pasal 285 KUHP, yang berbunyi sebagai berikut :

"Barangsiapa dengan kekerasan atau dengan ancaman kekerasan memaksa seorang wanita bersetubuh dengan dia di luar pernikahan, diancam karena melakukan perkosaan, dengan pidana penjara paling lama dua belas tahun"

Adapun unsur dari Pasal 285 KUHP yaitu sebagai berikut :

a. Barang siapa ;

b. Dengan kekerasan atau ancaman kekerasan;

c. Memaksa seseorang wanita bersetubuh dengan dia di luar perkawinan;

\section{Kesimpulan}

Berdasarkan uraian dan bahasan pada bab sebelumnya, maka penulis memberikan kesimpulan sebagai berikut:

1. Pemberian sanksi pidana tidak maksimum bagi pelaku tindak pidana pemerkosaan pada Putusan Nomor 131/Pid.B/2019/PN.Cbi belum mampu memberikan rasa keadilan bagi korban, karena dalam prakteknya aparat penegak hukum termasuk didalamnya majelis hakim yang seharusnya menjadi corong keadilan ternyata tidak memberikan sanksi yang maksimal kepada pelaku, majelis hakim dalam perkara tersebut bahkan secara terang-terangan mengabaikan kondisi korban yang mengalami trauma dan depresi. Hal tersebut memberikan bukti nyata bahwa masih minimnya jaminan perlindungan terhadap korban kekerasan seksual khususnya pemerkosaan dalam peradilan pidana Indonesia.

2 Pertimbangan hakim dalam memutus perkara tindak pidana pemerkosaan pada putusan No. 131/Pid.B/2019/PN.Cbi yang memberikan sanksi pidana penjara selama 3 (tahun) yaitu pada saat melakukan perbuatannya pelaku sadar akan akibat yang ditimbulkan, pelaku dalam melakukan perbuatannya berada pada kondisi yang sehat dan cakap untuk mempertimbangkan perbuatannya. Hakim juga tidak 
melihat adanya alasan pembenar atau alasan pemaaf yang dapat menjadi alasan penghapusan pidana terhadap perbuatan yang dilakukan oleh pelaku. Majelis Hakim hanya melihat adanya hal-hal yang memberatkan yaitu perbuatan pelaku membuat saksi Erica Alendha Sari mengalami trauma psikis. Dalam perkara ini hakim tidak mempertimbangkan jaminan pemenuhan hak-hak korban kekerasan seksual khususnya pemerkosaan atas pemulihan yang harus diakomodir dalam setiap tahap sistem peradilan pidana. Untuk itu perlu adanya rumusan peraturan perundang-undangan yang memberikan jaminan pemenuhan hak atas penanganan termasuk didalamnya hak atas kerahasiaan identitas, hak atas perlindungan terkait dengan jaminan tidak disalahkan dan dituntut atas keterangannya dan juga hak atas pemulihan bagi korban kekerasan untuk dapat melanjutkan hidup.

E. Daftar Pustaka

\section{Buku}

Abdul Wahid dan Muhammad Irfan, Kekerasan Pada Korban Seksual, Bandung : Refika Aditama, 2000

.Adami Chazawi, Pelajaran Hukum Pidana, Bagian 1; Stelsel Pidana, Teori-Teori Pemidanaan \& Batas Berlakunya Hukum Pidana, Jakarta : PT. Raja Grafindo Persada, 2002.

Amir Ilyas, Asas-Asas Hukum Pidana, Yogyakarta : Rangkang Education Yogyakarta \& PuKAP-Indonesia, 2012.

Arif Gosita, Relevansi Viktimologi : Dengan Pelayanan Terhadap Para Korban Perkosaan, Jakarta; Ind.HillCo., 1987.

Barda Nawawi Arief, Bunga Rampai Kebijakan Hukum Pidana Perkembangan Penyususnan Konsep
KUHP Baru, Kencana Prenada Media Group, Jakarta, 2010.

Bismar Siregar, Keadilan Hukum dalam Berbagai Aspek Hukum Nasional, Jakarta : Rajawali, 2005.

Departemen Pendidikan Dan Kebudayaan, Kamus Besar Bahasa Indonesia edisi II, Jakarta, Balai Pustaka, 1997.

Doortje D Turangan, Penerapan Pasal 285 KUHP Tentang Pelaku Tindak Pidana Perkosaan, Karya Tulis Ilmiah tidak diterbitkan, Manado, Universitas Sam Ratulangi, 2011.

Farid, A.Z. Abidin dan Andi Hamzah, Bentuk-Bentuk Khusus Perwujudan Delik, Jakarta: Rajawali Pers, 2006.

Kartini Kartono, Patologi Sosial, Jakarta, Raja Grafindo, 2001.

Leden Marpaung, Asas Teori Praktik Hukum Pidana. Penerbit Sinar Grafika. Jakarta, 2005.

\section{-------------------, Kejahatan Terhadap Kesusilaan Dan Masalah Prevensinya, Jakarta, Sinar Grafika, 2004.}

Lilik Mulyadi, Seraut Wajah Putusan Hakim dalam Hukum Acara Pidana Indonesia: Perspektif, Teoritis, Praktik, Teknik Membuat dan Permasalahannya. Bandung: Citra Aditya Bakti, 2010.

Moeljatno, (Penerjemah) Kitab UndangUndang Hukum Pidana, Jakarta : Bumi Aksara, 2003.

P.A.F. Lamintang, Dasar-Dasar Hukum Pidana Indnesia, bandungg, PT .citra Aditya bakti 1997. Nyawa, Tubuh, dan Kesehatan, Cetakan Kedua, Jakarta, Sinar Grafika, 2012.

R. Soesilo, KUHP Serta KomentarKomentarnya Lengkap Dengan Pasal Demi Pasal, Bandung, Karya Nusantara Cetakan X, 1988.

R. Sugandhi, KUHP dan Penjelasannya. Surabaya: Usaha Nasional, 2001. 
Satochid Kartanegara, Kumpulan Catatan Kuliah Hukum Pidana II, disusun oleh Mahasiswa PTIK Angkatan V, Tahun 1955.

Soerjono Soekanto, Pengantar Penelitian Hukum (Jakarta: Universitas Indonesia, 2014.

Sudharmawatiningsih, Pengkajian tentang Putusan Pemidanaan Lebih Tinggi dari Tuntutan Jaksa Penuntut Umum: Laporan Penelitian, Jakarta: Puslitbang Hukum dan Peradilan Badan Litbang Diklat Kumdil Mahkamah Agung, 2015.

Tongat, Hukum Pidana Indonesia, Malang : UMM Press, 2008.

Tinjauan

Terhadap Subyek Hukum Dalam KUHP, Jakarta, Djambatan, 2003.

Zainal Abidin Farid, Hukum Pidana 1, Cetakan Kedua, Jakarta : Sinar Grafika, 2007.

Peraturan Perundang Undangan

Indonesia, Undang-Undang Dasar 1945 Amandemen

Hukum Pidana.

Kitab Undang-Undang , Undang-Undang No. 48

Tahun 2009 Tentang Kekuasaan Kehakiman.

Negeri Cibinong Pengadilan
78/PID.B/2016/PN.KRG

\section{Internet}

http;//hukum.kompasiana.com/2012/02/05/k riminalitas-meningkat-hukumindonesia-gagal-melindungirakyatnya/, diakses pada 03 Mei 2020 https://www.scribd.com/document /328696822/FEMINISTJURISPRUDENCE, diakses pada tanggal 18 Juli 2020. 